https://doi.org/10.18778/8142-301-4.28

Martyna Wilbrandt-Gotowicz*

\title{
ZDECENTRALIZOWANE \\ I SCENTRALIZOWANE POSTĘPOWANIA ADMINISTRACYJNE W UNII EUROPEJSKIEJ
}

\section{Uwagi wstępne}

Ujmowanie administracji publicznej w kategoriach decentralizacji bądź centralizacji jej zadań, kompetencji i środków odnoszone jest tradycyjnie do struktur państwowych. W opracowaniu przedstawiono szersze podejście, uwzględniające realia multicentryczności współczesnego systemu prawa, w tym wpływ prawodawstwa unijnego na postępowania administracyjne. Przyjęcie takiej perspektywy umożliwia identyfikację modeli proceduralnych różniących się sposobem podziału kompetencji do załatwienia sprawy administracyjnej między organy państw członkowskich i administrację UE.

Poszczególne akty sektorowe wiążą bowiem rozstrzyganie o prawach lub obowiązkach jednostki z wydawaniem aktów administracyjnych na poziomie krajowym bądź unijnym. Możliwe jest więc wyróżnienie procedur determinowanych unijnym prawem formalnym (postępowań zintegrowanych z prawem $\mathrm{UE}^{1}$ ) odpowiednio o zdecentralizowa-

* Martyna Wilbrandt-Gotowicz - doktor nauk prawnych, Katedra Postępowania Administracyjnego, Uniwersytet Kardynała Stefana Wyszyńskiego w Warszawie.

${ }^{1}$ Szerzej M. Wilbrandt-Gotowicz, Zintegrowane z prawem Unii Europejskiej postępowania administracyjne, Warszawa 2017, s. 257-274. 
nym albo scentralizowanym charakterze. Odznaczają się one ponadto prostym lub złożonym układem stosunku administracyjnoprawnego, co przemawia za wyjątkowością modeli postępowań kształtowanych pod wpływem regulacji unijnych i ich różnorodnością niespotykaną w ujęciu wyłącznie prawa krajowego.

W związku z powyższym, w opracowaniu odniesiono się do specyfiki zjawisk decentralizacji i centralizacji procedur administracyjnych w UE, jak również przybliżono istotę postępowań scentralizowanych oraz postępowań zdecentralizowanych, z uwzględnieniem potencjalnych problemów w zakresie stosowania prawa charakterystycznych dla poszczególnych sposobów podziału kompetencji między organy krajowe i unijne.

\section{Decentralizacja i centralizacja postępowań administracyjnych w Unii Europejskiej}

W klasycznym ujęciu decentralizacja administracji zachodzi, gdy określone sprawy przekazywane są jako zadania własne podmiotom samorządowym. Następuje wówczas przesunięcie ciężaru administrowania na organy niższych szczebli (dekoncentracja) połączone z wyposażeniem tych organów w samodzielność i względną niezależność. Au rebours centralizacja polega na tym, iż w określonej sferze właściwości (kompetencji rzeczowej) system organów administracji jest zorganizowany w ten sposób, że podejmowanie decyzji należy wyłącznie do organów wyższych².

Wskazane mechanizmy można odpowiednio odnieść także do ram funkcjonowania Unii Europejskiej. W takim wypadku do szeroko rozumianej administracji europejskiej należałoby zaliczyć organy administracyjne państw członkowskich, jak również administrację UE obejmującą unijne instytucje, organy i jednostki organizacyjne wyposażone w kompetencje do podejmowania czynności w toku postępowań ad-

\footnotetext{
${ }^{2}$ Zob. E. Ochendowski, Prawo administracyjne - część ogólna, Toruń 2013, s. 233.
} 
ministracyjnych ${ }^{3}$. Administracja europejska odznacza się bowiem zespoleniem informacji, działań i kontroli, którego podstawą pozostają administracje państw członkowskich, funkcjonalnie powiązane w sieć przy współudziale jednostek administracyjnych poziomu $\mathrm{UE}^{4}$.

Wobec wielości podmiotów administrujących w Unii kluczowe znaczenie ma rozdzielenie uprawnień orzeczniczych. W perspektywie ogólnej jest ono pochodną traktatowego podziału kompetencji między Unię i państwa członkowskie (zgodnie z zasadą przyznania ${ }^{5}$ ). $\mathrm{Z}$ art. 2 ust. 1 i 2 TFUE wynika przy tym kategoryzacja na kompetencje wyłączne $\mathrm{UE}^{6}$ oraz dzielone z państwami członkowskimi (tzw. shared competences) ${ }^{7}$. Cechą charakterystyczną tych ostatnich jest utrata kompetencji państw w wyniku jej wykonania przez UE określana jako skutek prekluzyjny lub efekt zajętego pola (ang. pre-emption $)^{8}$. W ramach obszarów regulacyjnych przekazanych traktatowo Unii do kompetencji wyłącznej lub w których wykonuje ją ona w stosunku do kompetencji dzielonych (zgodnie ze wskazanym mechanizmem pierwszeństwa), to poszczególne akty sektorowe determi-

${ }^{3}$ Na możliwość takiej interpretacji na tle art. 298 ust. 1 TFUE wskazuje P. Craig - P. Craig, A general law on administrative procedure, legislative competence and judicial competence, „European Public Law” 2013/3, s. 511-512.

${ }_{4}^{4}$ E. Schmidt-Aßmann, Ogólne prawo administracyjne jako idea porządku. Założenia i zadania tworzenia systemu prawnoadministracyjnego, Warszawa 2011, s. 50.

${ }^{5}$ Zasada przyznania wyznacza, zgodnie z art. 5 ust. 1 TUE, granice kompetencji Unii, a ich wykonywanie podlega zasadom pomocniczości i proporcjonalności. Zasada kompetencji przyznanych polega na tym, iż UE działa wyłącznie w granicach kompetencji przydzielonych jej przez państwa członkowskie w traktatach do osiągnięcia określonych w nich celów. Wszelkie kompetencje nieprzyznane Unii w traktatach należą natomiast do państw członkowskich (art. 5 ust. 2 TUE).

6 „Jeżeli Traktaty przyznają Unii wyłączną kompetencję w określonej dziedzinie, jedynie Unia może stanowić prawo oraz przyjmować akty prawnie wiążące, natomiast Państwa Członkowskie mogą to czynić wyłącznie z upoważnienia Unii lub w celu wykonania aktów Unii" - art. 2 ust. 1 TFUE.

7 „Jeżeli Traktaty przyznają Unii w określonej dziedzinie kompetencję dzieloną z Państwami Członkowskimi, Unia i Państwa Członkowskie mogą stanowić prawo i przyjmować akty prawnie wiążące w tej dziedzinie. Państwa Członkowskie wykonują swoją kompetencję w zakresie, w jakim Unia nie wykonała swojej kompetencji. Państwa Członkowskie ponownie wykonują swoją kompetencję w zakresie, w jakim Unia postanowiła zaprzestać wykonywania swojej kompetencji” - art. 2 ust. 2 TFUE.

${ }^{8}$ P. Saganek, Nowe reguły dotyczace podziału kompetencji między Unię Europejska a państwa członkowskie w świetle Traktatu z Lizbony, „Przegląd Sejmowy” 2010/4, s. 102. 
nują rodzaj podmiotów uprawnionych do załatwiania spraw administracyjnych z danego obszaru. Regulacje sektorowe określają przy tym jako właściwe konkretne podmioty unijne albo zobowiązują państwa członkowskie do wyznaczenia organów krajowych odpowiednich do realizacji obowiązków wynikających z rozporządzenia czy dyrektywy (w tym np. wydawania decyzji administracyjnych).

Organy uprawnione do dokonywania czynności procesowych w postępowaniach administracyjnych z zakresu prawa unijnego odznaczają się zatem wyraźną dychotomią strukturalną - są to bowiem bądź podmioty administracyjne funkcjonujące w ramach aparatu administracyjnego UE jako organizacji międzynarodowej, bądź organy mieszczące się w strukturze administracyjnej poszczególnych państw członkowskich. Niekiedy tworzy się również specyficzne gremia złożone z przedstawicieli różnych państw członkowskich lub instytucji unijnych, nazywane mixed administration ${ }^{9}$. Odmienne są podstawy prawne funkcjonowania tych podmiotów, ich organizacja czy zasięg oddziaływania podejmowanych działań administracyjnych. Generalnie jednak podział na organy krajowe i organy UE (w tym administrację mieszaną) odpowiada występującemu w doktrynie rozdziałowi na pośrednie (zdecentralizowane) i bezpośrednie (scentralizowane) wykonywanie prawa unijnego ${ }^{10}$.

Szukając analogii do organów niższego i wyższego szczebla występujących w doktrynalnych opisach terminów centralizacji i decentralizacji, do tych pierwszych można zaliczyć organy krajowe, do drugich zaś - organy unijne. Co jednak istotne, w obrębie UE kontrowersyjne mogłoby być łączenie omawianych pojęć z hierarchicznym podporządkowaniem właściwym ujęciu krajowemu. W klasycznym rozumieniu centralizacja wiąże się bowiem $\mathrm{z}$ hierarchicznym pod-

${ }^{9} \mathrm{~Np}$. działające przy Komisji komitety stanowiące reprezentację państw członkowskich czy grupy koordynacyjne powoływane do rozstrzygania sporów w sprawach wzajemnego uznawania. Zob. E. Chiti, Administrative proceedings involving European agencies, „Law and Contemporary Problems” 2004/1, s. 222 i 225.

10 Zob. A. Wróbel, Wpływ prawa europejskiego na prawo o postępowaniu administracyjnym [w:] Administracja pod wpływem prawa europejskiego, red. J. Jagoda, B. Dolnicki, Bydgoszcz-Katowice 2006, s. 148; E. Schmidt-Aßmann, Ogólne..., s. 484. 
porządkowaniem organów administracji niższych szczebli organom wyższym, co przejawia się w zależności służbowej bądź osobowej ${ }^{11}$. Takich zależności organów krajowych względem instytucji unijnych być nie powinno. Wskazać jednak należy na występowanie specyficznej korelacji funkcjonalnej, która jest pochodną zasad prawa unijnego. Wszystkie organy państw członkowskich zobowiązane są bowiem respektować w swej działalności zasadę pierwszeństwa prawa unijnego, a także zapewniać wydawanie rozstrzygnięć odpowiadających wymogom jego efektywności (warunkom skuteczności i równoważności) ${ }^{12}$. Szczególny typ funkcjonalnego podporządkowania organów krajowych instytucjom unijnym jest ponadto widoczny w postępowaniach o charakterze wielostopniowym, złożonym (niem. mehrstufige ${ }^{13}$, ang. composite, mixed administrative proceedings $\left.{ }^{14}\right)$, w których sprawę rozstrzyga się na poziomie unijnym, jednak w toku postępowania organy państw członkowskich zobowiązane są do dokonywania określonych czynności (np. związanych z wstępną oceną podania czy przeprowadzeniem postępowania wyjaśniającego).

Mimo braku klasycznego hierarchicznego podporządkowania dychotomia podmiotów rozstrzygających sprawy administracyjne determinowane prawem unijnym (powiązana $\mathrm{z}$ zasięgiem terytorialnym ich rozstrzygnięć), jak również funkcjonalna zależność podmiotów krajowych wynikająca $\mathrm{z}$ wymogu respektowania zasad prawa unijnego, przemawiają za możliwością oceny postępowań zintegrowanych w kategoriach procedur zdecentralizowanych lub scentralizowanych.

${ }_{11}$ Zob. E. Ochendowski, Prawo..., s. 234.

12 Szerzej N. Półtorak, Zasada efektywnego wykonywania prawa Unii w sferze administracyjnego pośredniego wykonywania prawa Unii Europejskiej przez państwa członkowskie [w:] System Prawa Administracyjnego, t. 3, Europeizacja prawa administracyjnego, red. R. Hauser, Z. Niewiadomski, A. Wróbel, Warszawa 2014, s. 194 i n.

${ }_{13}$ Zob. H.P. Nehl, Europäisches Verwaltungsverfahren und Gemeinschaftsverfassung. Eine Studie gemeinschaftsrechtlicher Verfahrensgrundsätze unter besonderer Berücksichtigung „mehrstufiger” Verwaltungsverfahren, Berlin 2002, s. 29.

${ }_{14}$ Zob. H.C.H. Hoffmann, G.C. Rowe, A.H. Türk, Administrative law and policy of the European Union, New York 2011, s. 361-362; C. Franchini, European principles governing national administrative proceedings, "Law and Contemporary Problems" 2004/1, s. 184; G. della Cananea, The European Union's mixed administrative proceedings, „Law and Contemporary Problems” 2004/1, s. 197 i n. 
Wziąwszy pod uwagę występowanie dwóch poziomów rozstrzygania spraw administracyjnych (poziom unijny - scentralizowany oraz poziom krajowy - zdecentralizowany), odniosę się również do zjawisk decentralizacji i centralizacji jako pewnych procesów. Ponieważ kompetencje UE wynikają z ich przekazania przez państwa członkowskie, w zakresie spraw rozstrzyganych przez instytucje unijne można mówić o pewnego typu centralizacji. Przebiega ona kilkufazowo. W pierwszej kolejności państwa członkowskie traktatowo przyznały UE kompetencje w określonych dziedzinach (jako kompetencje wyłączne lub dzielone). W kolejnym etapie, w ramach działalności prawodawczej, ustanawiane są akty sektorowe, które mogą przyznawać właściwość rzeczową do załatwiania poszczególnych typów spraw podmiotom unijnej administracji. Aktualizuje się ona natomiast w ramach konkretnych postępowań administracyjnych.

Centralizacja procedur generalnie wiąże się zatem z przekazaniem kompetencji w dziedzinach pierwotnie przynależnych administracji krajowej podmiotom unijnym. Jest immanentnie związana z uczestnictwem państw członkowskich w strukturach UE. Nie przekłada się to jednak bezpośrednio na przejęcie konkretnych uprawnień do podejmowania decyzji od organów krajowych na rzecz administracji unijnej. Przedmiot unijnej regulacji może bowiem obejmować wydawanie aktów administracyjnych w sprawach, które nie miały odpowiedników w prawie krajowym, co związane jest z ogólnym wzrostem wagi regulacji administracyjnych, w tym na skutek działalności prawodawczej $\mathrm{UE}^{15}$.

Warto zastanowić się nad identyfikacją również procesów przeciwnych, związanych z przesuwaniem ciężaru administrowania $\mathrm{z}$ organów unijnych na rzecz organów krajowych. Zjawisko to odpowiada ewentualnemu odstępowaniu UE od regulacji w sferach kompetencji współdzielonych z państwami członkowskimi ${ }^{16}$. W przypadku nie-

15 Zob. H.C.H. Hofmann, G.C. Rowe, A.H. Türk, Administrative..., s. 3; L. Azoulay, Extention et élévation du champ du droit administratif européen [w:] What's the new in European administrative law? Quoi de neuf en droit administratif européen?, red. J. Ziller, San Domenico 2005, s. 43.

${ }^{16} \mathrm{Na}$ możliwość przejmowania na powrót niektórych kompetencji UE przez władze krajowe jako przejawu renacjonalizacji procesów integracyjnych zwraca uwagę 
skuteczności unormowań unijnych czy problemów z ich stosowaniem możliwe jest uchylenie danej dyrektywy czy rozporządzenia. Jeśli nie zostaną one zastąpione nowym aktem, kompetencja prawodawcza wraca do państw członkowskich (zgodnie z teorią zajętego pola). Do ustawodawstwa wewnętrznego należy wówczas ewentualne wskazanie organów, które przejmą zadania wykonywane uprzednio przez administrację unijną.

O swoistej decentralizacji można również mówić w kontekście procedur transnarodowych, które rozwijane są obecnie już nie tyle na podstawie umów bilateralnych, ile aktów sektorowych. Postępowania te mają charakter horyzontalny. Są współprowadzone przez organy $\mathrm{z}$ różnych państw członkowskich bądź opierają się na kompleksach zależnych od siebie procedur krajowych prowadzonych przez organy z różnych państw członkowskich. Dotyczą najczęściej sfer objętych materialnoprawną regulacją UE (np. w zakresie wzajemnego uznawania pozwoleń dopuszczających do obrotu produkty biobójcze). Decentralizacja w tym kontekście wiąże się zatem z przekazywaniem organom krajowym kompetencji, które są pochodną działalności prawodawczej UE.

Z europeizacją administracyjnego prawa procesowego sprzężone są zatem wzajemnie przenikające się procesy centralizacji i decentralizacji kompetencji organów administracji publicznej jako następstwa podziału kompetencji między Unię i państwa członkowskie. Odpowiada to wielokierunkowym oddziaływaniom poszczególnych krajowych systemów prawnych i systemu unijnego, czego rezultatem jest wyróżnianie zarówno wpływów o charakterze top-down („z góry do dołu”), jak i bottom-up („z dołu do góry”), czy wręcz europeizacji dwukierunkowej, będącej wyrazem zintegrowanego podejścia badawczego ${ }^{17}$. Na tym tle poniżej przedstawiono modele postępowań

R. Grzeszczak (R. Grzeszczak, Rozwój prawa Unii Europejskiej - od unifikacji i konstytucjonalizacji do fragmentacji i renacjonalizacji prawa [w:] Prawne problemy i wyzwania Unii Europejskiej, red. Ł. Pisarczyk, Warszawa 2017, s. 16).

17 Zob. J. Ruszkowski, Ponadnarodowość w systemie politycznym Unii Europejskiej, Warszawa 2010, s. 362; K. Wach, Europeizacja - próba systematyki i konceptualizacji podejść badawczych, „Horyzonty Polityki” 2013/8, s. 22 i n. 
determinowanych prawem unijnym o charakterze scentralizowanym oraz zdecentralizowanym, wskazując na ich cechy charakterystyczne oraz potencjalne problemy praktyczne.

\section{Postępowania scentralizowane}

W postępowaniach scentralizowanych rozstrzygnięcie sprawy administracyjnej zapada na poziomie unijnym, a akt kształtujący sytuację prawną jednostki pochodzi od organu ponadpaństwowego. Powinien być on zatem rozpatrywany jako tzw. unijny akt administracyjny ${ }^{18}$. Rozstrzygnięcia instytucji unijnych nie mają przy tym jednorodnej formy. Przyjmują postać aktów indywidualnych (np. decyzji o odmowie udzielenia pozwolenia) albo generalnych aktów administracyjnych (np. pozwolenia na obrót wydawanego $\mathrm{w}$ formie rozporządzenia wykonawczego Komisji). Co do zasady terytorialny zakres ich związania obejmuje obszar całej Unii.

Postępowania scentralizowane mogą mieć formę prostą bądź złożoną. W pierwszym modelu administracja unijna podejmuje rozstrzygnięcia bez udziału organów krajowych jako podmiotów współdziałających czy współprowadzących postępowanie. W tego typu procedurach zastosowanie znajdują zatem wyłącznie regulacje procesowe pochodzenia unijnego. Dotyczą one różnorodnych sfer reglamentacji wspólnego rynku (np. wydawania unijnych pozwoleń dopuszczających do obrotu produkty lecznicze ${ }^{19}$, zezwoleń na wprowadzanie nowej żywności na rynek w Unii ${ }^{20}$ czy zezwoleń w zakresie handlu

${ }^{18}$ Szerzej M. Jaśkowski, Sądowa kontrola legalności aktów administracyjnych Unii Europejskiej, Warszawa 2016, s. 55 i n.

19 Por. np. rozporządzenie (WE) nr 726/2004 Parlamentu Europejskiego i Rady z 31.03.2004 r. ustanawiające wspólnotowe procedury wydawania pozwoleń dla produktów leczniczych stosowanych u ludzi i do celów weterynaryjnych i nadzoru nad nimi oraz ustanawiające Europejską Agencję Leków (Dz.Urz. WE L 136, s. 1 ze zm.).

20 Zob. rozporządzenie Parlamentu Europejskiego i Rady (UE) 2015/2283 z 25.11.2015 r. w sprawie nowej żywności, zmieniające rozporządzenie Parlamentu Europejskiego i Rady (UE) nr 1169/2011 oraz uchylające rozporządzenie (WE) nr 258/97 Parlamentu Europejskiego i Rady oraz rozporządzenie Komisji (WE) nr 1852/2001 (Dz.Urz. UE L 327, s. 1). 
chemikaliami ${ }^{21}$ ). Choć organy państw członkowskich mogą być informowane o dokonywanych czynnościach oraz przedkładać swoje stanowiska, ich rola sprowadza się do uczestnictwa charakterystycznego dla stron postępowań, nie zaś organów współdziałających w wydawaniu rozstrzygnięcia.

Inaczej jest w modelu scentralizowanym złożonym, w którym chociaż rozstrzygnięcie sprawy administracyjnej pozostawiono administracji unijnej, w toku postępowania część czynności procesowych wykonywanych jest przez organy krajowe. Wydanie aktu administracyjnego jest zatem poprzedzone procedurą krajową o różnym zakresie (od przyjęcia wniosku, poprzez ocenę formalną, a niekiedy również przeprowadzenie postępowania wyjaśniającego). Część czynności procesowych dokonywanych jest więc przez organ danego państwa, zwany niekiedy organem referencyjnym. Umożliwia to wyróżnienie w ramach postępowania scentralizowanego złożonego czynności (fazy) postępowania przed organem krajowym, której zasadniczym elementem może być wydanie stanowiska (opinii, raportu) oraz czynności (fazy) postępowania unijnego zmierzającego do wiążącego rozstrzygnięcia sprawy, np. przy wykorzystaniu przedstawionej przez organ krajowy oceny stanu faktycznego w sprawie ${ }^{22}$. Fazy te mogą nawzajem się przenikać, co akcentowane jest $\mathrm{w}$ doktrynie jako najbardziej interesujący aspekt krzyżowania się ponadnarodowego i krajowych poziomów administracji ${ }^{23}$.

${ }^{21}$ Por. rozporządzenie Parlamentu Europejskiego i Rady (WE) nr 1907/2006 z 18.12.2006 r. w sprawie rejestracji, oceny, udzielania zezwoleń i stosowanych ograniczeń w zakresie chemikaliów (REACH) i utworzenia Europejskiej Agencji Chemikaliów, zmieniającego dyrektywę 1999/45/WE oraz uchylającego rozporządzenie Rady (EWG) nr 793/93 i rozporządzenie Komisji (WE) nr 1488/94, jak również dyrektywę Rady 76/769/EWG i dyrektywy Komisji 91/155/EWG, 93/67/EWG, 93/105/WE i 2000/21/WE (Dz.Urz. WE L 396, s. 1 ze zm.).

${ }^{22}$ Procedury, których rozpoczęcie powierza się organom krajowym, podczas gdy ostateczne rozstrzygnięcie podejmowane jest na poziomie unijnym, określane są jako procedury typu bottom-up, w odróżnieniu od postępowań wszczynanych na poziomie unijnym, które kończą się krajowym rozstrzygnięciem kształtującym sytuację prawną jednostki, charakteryzowanych jako top-down procedures - zob. H.C.H. Hofmann, G.C. Rowe, A.H. Türk, Administrative..., s. 362. Szerzej G. della Cananea, The European..., s. 199-203.

23 S. Cassese, European administrative proceedings, „Law and Contemporary Problems” 2004/1, s. 23-24. Zob. również J.H. Jans, R. de Lange, S. Prechal, R.J.G.M. Widdershoven, Europeanisation of public law, Groningen 2007, s. 29. 
Postępowania scentralizowane złożone odznaczają się wertykalnym układem współdziałających organów: instytucji unijnych jako podmiotów centralnych obejmujących swoją działalnością całą UE oraz organów krajowych - jako podmiotów zdecentralizowanych właściwych w sprawach obejmujących obszar danego państwa członkowskiego. Efektywne prowadzenie tego typu postępowań wymaga zatem sprawnej współpracy między administracją unijną i administracją poszczególnych państw członkowskich. Brak jednolitości rozwiązań sektorowych w tym zakresie i ich fragmentaryczność mogą rodzić przy tym pewne obawy o odpowiednie zabezpieczenie gwarancji procesowych stron takich postępowań. Warto pamiętać, iż organy krajowe zazwyczaj współstosują w nich krajowe i unijne normy procesowe, choć główny ciężar ochrony praw procesowych spoczywa na unormowaniach krajowych. Są one bardziej szczegółowe niż unijne i powinny być posiłkowo stosowane w postępowaniach scentralizowanych złożonych względem aktów i czynności organów krajowych oraz ich zaskarżania, co odpowiada konstrukcji autonomii proceduralnej państw członkowskich.

W perspektywie administracji unijnej podkreślany jest również problem delegowania części zadań w postępowaniach scentralizowanych na podmioty wyspecjalizowane (np. Europejską Agencję Chemikaliów, Europejski Urząd ds. Bezpieczeństwa Żywności, Europejską Agencję Kolejową), co potęguje efekt współprowadzenia postępowania przez kilka organów ${ }^{24}$. Pełnią one funkcje regulacyjne oraz przygotowują projekty aktów, które są następnie przekazywane Komisji w celu podjęcia rozstrzygnięcia w konkretnej sprawie ${ }^{25}$.

\section{Postępowania zdecentralizowane}

W postępowaniach zdecentralizowanych sprawę administracyjną rozstrzyga krajowy organ administracji. Na gruncie prawa polskiego za-

${ }^{24} \mathrm{M}$. Wilbrandt-Gotowicz, Internacjonalne (zintegrowane) postępowanie administracyjne - zarys koncepcji [w:] Internacjonalizacja administracji publicznej, red. Z. Czarnik, J. Posłuszny, L. Żukowski, Warszawa 2015, s. 400-401.

${ }^{25}$ Zob. M. Shapiro, Independent Agencies [w:] The evolution of EU law, red. P. Craig, G. de Búrca, New York 2011, s. 112. 
kres podmiotowy i przedmiotowy tego typu postępowania odpowiada zakresowi postępowania jurysdykcyjnego określonego w art. 1 pkt 1 i 2 k.p.a. W perspektywie unijnej opisywana kategoria odnoszona jest przy tym do procedur, które posiadają częściową regulację w prawie unijnym (postępowań zintegrowanych z prawem UE). Oznacza to, iż organy administracji państw członkowskich zobowiązane są stosować w takich przypadkach nie tylko krajowe normy proceduralne niedeterminowane prawem unijnym, ale także (na zasadzie pierwszeństwa) unijne normy procesowe zawarte w bezpośrednio skutecznych rozporządzeniach, ewentualnie normy krajowe determinowane normami dyrektyw. Postępowania zdecentralizowane charakteryzują się zatem złożoną podstawą procesową czynności organów, w odróżnieniu od procedur, w których rozwiązania formalne nie są warunkowane prawem unijnym. Ustanawianie unijnych norm procesowych prowadzi przykładowo do sytuacji, w których organ krajowy, wszczynając postępowanie w sprawie wydania pozwolenia (np. na obrót danym produktem) czy zezwolenia (np. na wykonywanie zawodu przewoźnika drogowego) na terytorium tego państwa i na żądanie przedsiębiorcy mającego siedzibę w tym państwie, zobowiązany jest przy wydawaniu decyzji administracyjnej stosować w pierwszej kolejności nie krajowe przepisy proceduralne (Kodeks postępowania administracyjnego), lecz przepisy odpowiedniego aktu unijnego, ewentualnie przepisy krajowe implementujące dyrektywę ${ }^{26}$. Rodzi to określone problemy praktyczne związane $\mathrm{z}$ wyborem norm procesowych do zastosowania w postępowaniu, a następnie ich prawidłowym zastosowaniem. Względem instytucji procesowych nieuregulowanych w prawie unijnym adekwatne bowiem pozostają krajowe przepisy ogólnej procedury administracyjnej (ewentualnie przepisy szczególne), zgodnie z zasadą autonomii proceduralnej państw członkowskich. Ze względu jednak na fragmentaryczność i ramowość rozwiązań procesowych ujętych w aktach sektorowych, także w odniesieniu do instytucji prawnych w nich unormowanych posiłkowo stosuje się przepisy krajowe, rekonstruując normy o charakterze multicentrycznym. Ma to na celu zapewnienie efektywności prawa unijnego oraz zabezpieczenie

\footnotetext{
${ }^{26}$ Zob. M. Wilbrandt-Gotowicz, Zintegrowane..., s. 271.
} 
odpowiedniego poziomu gwarancji procesowych stron, które w szerszym zakresie akcentowane są w porządkach państw członkowskich.

W modelu prostym postępowań zdecentralizowanych brak jest wymogu bezpośredniego elementu transgraniczności. Inaczej jest w odniesieniu do złożonej postaci postępowań zdecentralizowanych. Należą do nich procedury, w których rozstrzygnięcia zapadają co prawda na poziomie krajowym, jednak w załatwieniu sprawy współuczestniczą organy z różnych państw członkowskich. Do wskazanych już wyżej problemów związanych ze współstosowaniem norm krajowych i unijnych dochodzi dodatkowo konieczność współpracy czy też współdziałania między organami z różnych państw członkowskich o odmiennym reżimie prawnym. Ramy sprawy administracyjnej w postępowaniach zdecentralizowanych złożonych wykraczają przy tym poza obszar jednego państwa. Sprawia to, iż ustalenie sytuacji prawnej jednostki wymaga wydania w porozumieniu $z$ organami z różnych państw rozstrzygnięcia obejmującego swym zasięgiem więcej niż jedno państwo (np. przy decyzjach w sprawie przemieszczania odpadów albo zezwoleń na międzynarodowy przewóz autokarowy), ewentualnie powiązanych ze sobą rozstrzygnięć organów krajowych (jak w procedurach wzajemnego uznawania pozwoleń). Postępowania te charakteryzują się układem horyzontalnym, stąd zaliczane są przez S. Cassesa do procedur opartych na elemencie wewnątrznarodowym (ang. infranational), w odróżnieniu od procedur o charakterze krajowym, narodowym (ang. national) i unijnym, ponadnarodowym (ang. supranational) ${ }^{27}$.

W różny sposób uregulowane mogą być zależności między nimi. Rozstrzygnięcie organu jednego państwa członkowskiego może stanowić prejudykat dla rozstrzygnięć analogicznych organów innych państw członkowskich (np. w uznaniu sekwencyjnym). W innym wariancie (np. w uznaniu równoległym) jeden wniosek o wszczęcie postępowania

27 Por. S. Cassese, European..., s. 34. W języku polskim lepszym określeniem byłoby odwołanie się do pojęcia procedur transnarodowych, związanych z elementem sprawy administracyjnej wykraczającym poza obszar jednego państwa, a znajdującym się w sferze działania administracji także innego lub innych państw. M. Wilbrandt-Gotowicz, Zintegrowane..., s. 254. 
może spowodować stan zawisłości sprawy administracyjnej przed organami różnych państw członkowskich i zobowiązywać je do wydania rozstrzygnięć o jednolitym lub zbliżonym charakterze, choć zakres postępowań prowadzonych w poszczególnych krajach może być różny (np. jedno państwo jako referencyjne prowadzi pełne postępowanie wyjaśniające, a inne korzystają z jego ustaleń) ${ }^{28}$. Tego typu procedury są zatem przejawem złożonej kooperacji właściwych organów przy rozstrzyganiu spraw administracyjnych, współpracy, która wykracza poza ramy zwykłej pomocy prawnej (np. w postaci przekazywania dokumentów) i ma charakter obligatoryjny dla spraw określonego rodzaju ${ }^{29}$.

\section{Podsumowanie}

Jednym z następstw europeizacji prawa jest kształtowanie się różnorodnych modeli procedur administracyjnych. Do ich opisu można adaptować pojęcia charakterystyczne dla struktur administracji krajowej, w tym centralizacji i decentralizacji. Zjawiska te w odniesieniu do postępowań administracyjnych w Unii Europejskiej nie są jednak powiązane z hierarchicznym podporządkowaniem organów niższego stopnia organom wyższego stopnia, tak jak ma to miejsce w porządku wewnętrznym. Trafnie ilustrują natomiast różne poziomy rozstrzygania spraw administracyjnych: scentralizowany - przez organy, instytucje czy jednostki organizacyjne UE oraz zdecentralizowany - przez organy państw członkowskich, jak również ich powiązanie wspólnym rdzeniem, jaki stanowią zasady ogólne prawa UE, w tym zasady pierwszeństwa i efektywności.

Wzajemne przenikanie się w prawodawstwie unijnym tendencji botom-up (centralizacyjnych) oraz top-down (decentralizacyjnych) uwidacznia złożoność współczesnych struktur administracji publicznej, zwłaszcza w perspektywie podmiotów uczestniczących w rozstrzyga-

${ }^{28}$ Por. art. 33, 34 i 53 rozporządzenia (UE) Parlamentu Europejskiego i Rady nr 528/2012 z 22.05.2012 r. w sprawie udostępniania na rynku i stosowania produktów biobójczych (Dz.Urz. UE L 167, s. 1 ze zm.).

${ }_{29}$ M. Wilbrandt-Gotowicz, Zintegrowane..., s. 273. 
niu spraw administracyjnych. Wskazane modele proceduralne oparte są bowiem nie tylko na klasycznym ujęciu jednostkowego organu właściwego do załatwienia danej sprawy (modele proste), ale również na złożonych układach współdziałających ze sobą podmiotów krajowych z różnych państw bądź organów krajowych i unijnych (modele złożone). Ta heterogeniczność, wielopostaciowość modeli proceduralnych może rodzić istotne problemy praktyczne związane ze współstosowaniem norm prawnych różnego pochodzenia. Podkreślić ponadto należy wagę standardów komunikacji i współpracy między organami różnego szczebla, jak i z różnych państw, które zobowiązane są na podstawie poszczególnych regulacji sektorowych do współdziałania w postępowaniach zintegrowanych z prawem $\mathrm{UE}^{30}$.

\section{Bibliografia:}

Azoulay L., Extention et élévation du champ du droit administratif européen [w:] What's the new in European administrative law? Quoi de neuf en droit administratif européen?, red. J. Ziller, San Domenico 2005

della Cananea G., The European Union's mixed administrative proceedings, „Law and Contemporary Problems" 2004/1

Cassese S., European administrative proceedings, „Law and Contemporary Problems" 2004/1

Chiti E., Administrative proceedings involving European agencies, „Law and Contemporary Problems" 2004/1

Craig P., A general law on administrative procedure, legislative competence and judicial competence, „European Public Law” 2013/3

Franchini C., European principles governing national administrative proceedings, "Law and Contemporary Problems" 2004/1

Grzeszczak R., Rozwój prawa Unii Europejskiej - od unifikacji i konstytucjonalizacji do fragmentacji i renacjonalizacji prawa [w:] Prawne problemy $i$ wyzwania Unii Europejskiej, red. Ł. Pisarczyk, Warszawa 2017

${ }^{30}$ Na tym tle pozytywnie należy ocenić wprowadzenie do Kodeksu postępowania administracyjnego ustawą z 7.04.2017 r. o zmianie ustawy - Kodeks postępowania administracyjnego oraz niektórych innych ustaw (Dz.U. poz. 935) działu VIIIa, dotyczącego europejskiej współpracy administracyjnej. 
Hoffmann H.C.H., Rowe G.C., Türk A.H., Administrative law and policy of the European Union, New York 2011

Jans J.H., de Lange R., Prechal S., Widdershoven R.J.G.M., Europeanisation of public law, Groningen 2007

Jaśkowski M., Sądowa kontrola legalności aktów administracyjnych Unii Europejskiej, Warszawa 2016

Nehl H.P., Europäisches Verwaltungsverfahren und Gemeinschaftsverfassung. Eine Studie gemeinschaftsrechtlicher Verfahrensgrundsätze unter besonderer Berücksichtigung „mehrstufiger” Verwaltungsverfahren, Berlin 2002

Ochendowski E., Prawo administracyjne - część ogólna, Toruń 2013

Półtorak N., Zasada efektywnego wykonywania prawa Unii w sferze administracyjnego pośredniego wykonywania prawa Unii Europejskiej przez państwa członkowskie [w:] System Prawa Administracyjnego, t. 3, Europeizacja prawa administracyjnego, red. R. Hauser, Z. Niewiadomski, A. Wróbel, Warszawa 2014

Ruszkowski J., Ponadnarodowość w systemie politycznym Unii Europejskiej, Warszawa 2010

Saganek P., Nowe reguły dotyczące podziału kompetencji między Unię Europejska a państwa członkowskie w świetle Traktatu z Lizbony, „Przegląd Sejmowy” 2010/4

Schmidt-Aßmann E., Ogólne prawo administracyjne jako idea porządku. Założenia i zadania tworzenia systemu prawnoadministracyjnego, Warszawa 2011

Shapiro M., Independent Agencies [w:] The evolution of EU law, red. P. Craig, G. de Búrca, New York 2011

Wach K., Europeizacja - próba systematyki i konceptualizacji podejść badawczych, „Horyzonty Polityki” 2013/8

Wilbrandt-Gotowicz M., Internacjonalne (zintegrowane) postępowanie administracyjne - zarys koncepcji [w:] Internacjonalizacja administracji publicznej, red. Z. Czarnik, J. Posłuszny, L. Żukowski, Warszawa 2015

Wilbrandt-Gotowicz M., Zintegrowane z prawem Unii Europejskiej postępowania administracyjne, Warszawa 2017

Wróbel A., Wpływ prawa europejskiego na prawo o postępowaniu administracyjnym [w:] Administracja pod wpływem prawa europejskiego, red. J. Jagoda, B. Dolnicki, Bydgoszcz-Katowice 2006 